\title{
Rencana Zonasi Kawasan Konservasi Perairan Daerah Kota Pariaman, Provinsi Sumatera Barat
}

\author{
Zonation Plan of Marine Protected Area Pariaman City, West Sumatra Province
}

\author{
Suparno $^{1 *}$ \\ ${ }^{1}$ Program Studi Pemanfaatan Sumberdaya Perikanan, Universitas Bung Hatta, Padang, \\ 25133, Indonesia \\ *Korespondensi : suparnopranoto@bunghatta.ac.id
}

\begin{abstract}
ABSTRAK
Kawasan Konservasi Perairan Daerah Kota Pariaman adalah kawasan perairan yang dilindungi dan dikelola meliputi perairan pesisir dan perairan Pulau Angso, Pulau Tangah, Pulau Ujuang dan Pulau Kasiak. Tujuan penelitian adalah menganalisis Rencana Zonasi Kawasan Konservasi Perairan dan menganalisis kegiatan yang boleh dan tidak boleh dilakukan di Daerah Kota Pariaman. Metode penelitian yang digunakan metode deskriptif. Hasil analisis rencana zonasi kawasan konservasi seluas 11.776,63 ha terbagi atas 3 zona yaitu zona inti $249.31 \mathrm{Ha}(2,12 \%)$, zona perikanan berkelanjutan 11.460.32 ha $(97,31 \%)$ dan zona pemanfaatan $67,0 \mathrm{Ha}(0,57 \%)$. Kegiatan yang boleh dilakukan di zona inti adalah penelitian, rehabilitasi ekosistem dan restocking alami. Kegiatan yang boleh dilakukan di zona perikanan berkelanjutan adalah untuk wisata, penelitian, penangkapan ikan, rehabilitasi ekosistem, budidaya ikan dan restocking alami. Kegiatan yang boleh dilakukan di zona pemanfaatan adalah untuk wisata, penelitian, rehabilitasi ekosistem, dan restocking alami. Kegiatan yang tidak boleh dilakukan zona inti adalah wisata, penangkapan ikan, budidaya ikan dan aktifitas menghilangkan fungsi kawasan. Kegiatan yang tidak boleh dilakukan di zona perikanan berkelanjutan adalah aktifitas menghilangkan fungsi kawasan. Kegiatan yang tidak boleh dilakukan di zona pemanfaatan adalah untuk penangkapan ikan, budidaya ikan, dan aktifitas menghilangkan fungsi kawasan. Rencana Zonasi Kawasan Konservasi Perairan adalah dokumen penting bagi Pemerintah Provinsi Sumatera Barat sebagai dasar untuk pemberian izin usaha perairan.
\end{abstract}

Kata kunci: Kawasan konservasi, Pariaman, rencana zonasi

\begin{abstract}
Pariaman City Marine Protected Area is a protected and managed water area including coastal waters of Angso Islands, Tangah Island, Ujuang Island, and Kasiak Island. The purpose of the study is to analyze the Zoning Plan of the Pariaman City Marine Protected Area and analyze the permitted and prohibited activities. The research method used a descriptive method. The results of the analysis of Zoning Plans for Marine Protected Areas covering an area of 11.776,63 Ha divided into 3 zones, namely no-take zone $249.31 \mathrm{Ha}(2,12 \%)$, sustainable fishery zones 11.460 .32 ha $(97,31 \%)$, and utilization zones $67,0 \mathrm{Ha}(0,57 \%)$. Permitted activities in the no-take zone are research, ecosystem rehabilitation, and natural restocking. Sustainable fisheries zone are allowed for tourism, research, fishing, ecosystem rehabilitation, aquaculture, and natural restocking. A utilization zone is allowed for tourism, research, ecosystem rehabilitation, and natural restocking. Tourism, fishing, aquaculture, and activities that eliminate the area functionality are prohibited in the no-take zone area. The Activity that removes the function of the area is also prohibited in the fishery zone area. Activities that are
\end{abstract}


forbidden in the utilization zone are for fishing, aquaculture, and activities that eliminate the function of the area. The Marine Protected Area Zoning Plan is an important document for the West Sumatra Provincial Government as the basis for granting marine business permits.

Keywords: Marine protected area, Pariaman, zoning plan

\section{PENDAHULUAN}

Kawasan konservasi perairan adalah kawasan perairan yang dikelola dengan aturan zonasi dalam rangka perlindungan sumberdaya ikan dan habitatnya. Rencana Zonasi Kawasan Konservasi Perairan adalah rencana alokasi ruang perairan berdasarkan ketentuan batas-batas fungsional kawasan dan kesesuaian daya dukung kawasan. Kawasan konservasi perairan berfungsi untuk melindungi biota perairan dan pengaturan pemanfaatan sumberdaya perikanan secara berkelanjutan. Pengaturan kawasan konservasi perairan melalui sistem zonasi dengan pembagian zona inti, zona pemanfaatan, zona perikanan berkelanjutan dan zona lainnya.

Luas kawasan pesisir yang dilindungi idealnya adalah $20-30 \%$ dari total luas perairan pesisir. Luas zona inti dalam Kawasan Konservasi Perairan minimum 20-30\% untuk menjaga keberlanjutan stok biota yang menjadi target pemanfaatan (Krueck et al., 2017). Kawasan Konservasi Laut dibuat untuk tujuan pengelolaan dan konservasi sumberdaya ikan (Perez-Ruzafa et al., 2017). Zona inti dilarang untuk menangkap ikan dalam rangka menjaga stok ikan (Giakoumi et al., 2017, Sala dan Giakoumi, 2017), meningkatkan kulitas habitat (Rodwell et al., 2003), mengembalikan fungsi ekosistem (Cheng et al., 2019) dan meningkat populasi dan biomassa hasil perikanan pada wilayah yang berdekatan (Harmelin-Vivien et al., 2008).

Kota Pariaman adalah salah satu kota di pesisir di Provinsi Sumatera Barat dengan letak geografis pada $0^{\circ} 33^{\prime} 00^{\prime \prime}$ $0^{\circ} 40^{\prime} 43^{\prime \prime}$ LS dan $100^{\circ} 10^{\prime} 33^{\prime \prime}-100^{\circ}$ 10 '55" BT. Kota Pariaman mempunyai luas wilayah daratan sebesar $73,36 \mathrm{~km}^{2}$ dan luas lautan 282,56 $\mathrm{km}^{2}$. Kota Pariaman mempunyai panjang pantai 19 $\mathrm{Km}$ dan mempunyai 4 pulau kecil yaitu Pulau Angso, Pulau Tangah, Pulau Ujuang dan Pulau Kasiak. Luas ekosistem mangrove sebesar 37,49 $\mathrm{Ha}$ dan luas terumbu karang 261,72 $\mathrm{Ha}$ (Dinas Kelautan dan Perikanan Provinsi Sumatera Barat, 2019). Berdasarkan Keputusan Gubernur Sumatera Barat No. 523.6/150-2017 tentang Pencadangan Kawasan Konservasi Daerah bahwa luas Kawasan Konservasi Perairan Daerah (KKPD) Kota Pariaman adalah seluas 11.776,63 ha. Pemanfaatan KKPD Kota Pariaman saat ini adalah untuk perikanan tangkap, wisata bahari, alur pelayaran, konservasi terumbu karang dan penyu.

Kajian rencana zonasi kawasan perairan di lokasi ini belum ada. Penelitian rencana zonasi kawasan perairan sangat penting untuk mengatur alokasi ruang laut sehingga tidak terjadi konflik kepentingan. Tahapan berikutnya setelah SK Pencanangan oleh gubernur adalah penyusunan Dokumen Rencana Zonasi dan Rencana Pengelolaan Kawasan Konservasi Perairan. Dalam rangka pengelolaan KKPD Kota Pariaman diperlukan kajian Rencana Zonasi KKPD Kota Pariaman. Tujuan penelitian adalah menganalisis rencana zonasi KKPD Kota Pariaman dan menganalisis kegiatan yang boleh dan tidak boleh dilakukan di KKPD Kota Pariaman.

\section{METODE PENELITIAN}

Lokasi penelitian adalah perairan laut KKPD Kota Pariaman diukur dari pantai pada waktu pasang tertinggi. Penelitian ini dilakukan Juni - September 2019. Metode penelitian yang digunakan adalah Metode Deskriptif yaitu metode 
penelitian yang menggambarkan karakteristik populasi atau fenomena yang sedang diteliti. Jenis data yang dikumpulkan terdiri 1. Data primer dari observasi, wawancara, Fokus Diskusi Group, kuisioner dan survey lapangan. 2. Data sekunder berasal dari Badan Informasi Geospasial (BIG), Kementrian Kelautan dan Perikanan, Perguruan Tinggi, BPSPL Padang, Laporan SKPD Pemerintah Provinsi Sumatera Barat, dan RTRW Kota Pariaman. Peta dasar berasal dari Peta Lingkungan Pantai Indonesia BIG skala 1: 50.000 dan 1:250.000 tahun 2012, dan Peta Rupa Bumi Indonesia skala 1: 50.000 tahun 2017.

Tahapan penyusunan Rencana Zonasi Kawasan Konservasi Perairan berdasarkan Buku Rencana Pengelolaan dan Zonasi Kawasan Konservasi Perairan (Kementrian Kelautan dan Perikanan, 2014) dan Peraturan Menteri Kelautan No 30/Men/2010 tentang Rencana Pengelolaan dan Zonasi Kawasan Konservasi Perairan (Kementrian Kelautan dan Perikanan, 2010).

Analisis data Rencana Zonasi

Kawasan Konservasi Perairan Kota Pariaman menggunakan Analisa Spasial, Non Spasial dan Kriteria Kesesuaian Lahan Perairan dari data sosial ekonomi, budaya dan biofisik perairan pesisir dan pulau-pulau kecil di KKPD Kota Pariaman. Analisa kesesuaian lahan dilakukan melalui prosedur analisa
Sistem Informasi Geografis (SIG) berupa tumpang susun (overlay) parameterparameter biofisik perairan pesisir. Hasil rumusan Peta Zonasi dan Arahan kegiatan pemanfaatan zona di KKPD Kota Pariaman dilakukan konsultasi publik.

\section{HASIL DAN PEMBAHASAN}

\section{Rencana Zonasi KKPD}

Kawasan Konservasi Perairan Daerah Kota Keputusan Gubernur Sumatera Barat No. 523.6/150-2017 tentang Pencadangan Kawasan Konservasi Daerah. Luas KKPD Kota Pariaman adalah 11.776,63 ha. yang meliputi perairan laut Kota Pariaman termasuk 4 perairan-pulau lkecil yaitu Pulau Angso, Pulau Tangah, Pulau Ujuang dan Pulau Kasiak.

Dalam penataan rencana zonasi KKPD Kota Pariaman, kawasan yang direncanakan secara garis besar dibagi 3 zona yaitu zona inti, zona perikanan berkelanjutan dan zona pemanfaatan. Berdasarkan luas kawasan total 11.776,63 ha dibagi menjadi 3 zona yaitu zona inti dengan luas $249,31 \mathrm{Ha}$ atau 2,12\%; zona perikanan berkelanjutan seluas $11.460,32$ ha atau $97,31 \%$ dan zona pemanfaatan 67,00 ha atau $0,57 \%$ dari luas kawasan perencanaan (Gambar 1 dan Tabel 1).

Tabel 1. Pembagian Rencana Zonasi KKPD Kota Pariaman

\begin{tabular}{lccl}
\hline \multicolumn{1}{c}{ Zona } & Luas (ha) & $\begin{array}{c}\text { Persentase } \\
(\mathbf{\%})\end{array}$ & \multicolumn{1}{c}{ Lokasi } \\
\hline Zona Inti & 249.31 & 2,12 & Perairan P. Kasiak \\
\hline $\begin{array}{l}\text { Zona Perikanan } \\
\text { Berkelanjutan }\end{array}$ & 11.460 .32 & 97,31 & $\begin{array}{l}\text { Perairan KKPD Kota } \\
\text { Pariaman }\end{array}$ \\
\hline Zona Pemanfaatan & 67,00 & 0,57 & $\begin{array}{l}\text { Perairan Pulau Angso, } \\
\text { Pulau Tangah dan Pulau } \\
\text { Ujuang }\end{array}$ \\
\hline \multicolumn{1}{c}{ Jumlah } & $11.776,63$ & 100,00 & \\
\hline
\end{tabular}




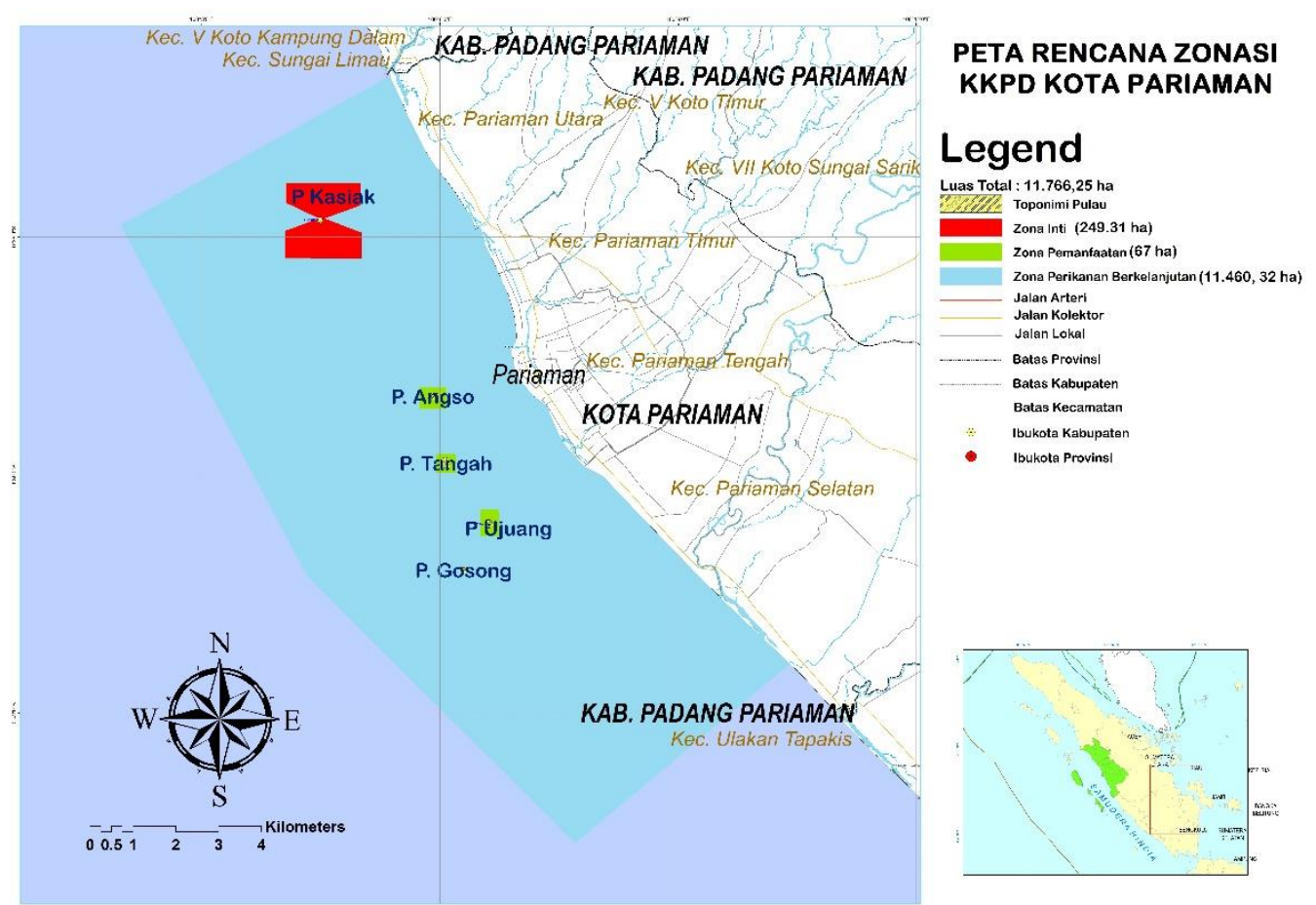

Gambar 1. Peta Rencana Zonasi KKPD Kota Pariaman

Berdasarkan Peraturan Menteri Kelautan dan Perikanan Nomor 30 tahun 2010 tentang rencana pengelolaan dan zonasi kawasan konservasi perairan bahwa zonasi kawasan konservasi perairan terbagi atas zona inti, zona perikanan berkelanjutan, zona pemanfaatan, dan zona lainnya. Penataan zonasi perairan dilaksanakan berdasarkan pertimbangan daya dukung dan kesetimbangan ekologis perairan (Kementrian Kelautan dan Perikanan, 2010).

Pulau Angso merupakan salah satu pulau dalam administrasi Kecamatan Pariaman Tengah, dengan koordinat terletak pada $00^{\circ} 38^{\prime} 01^{\prime \prime}$ LS dan $100^{\circ} 05^{\prime} 57^{\prime}$ BT. Luas Pulau Angso adalah 5,1 Ha. Pulau ini tidak berpenduduk dan kata Angso itu sendiri berarti Angsa. Kondisi umum Pulau Angso merupakan pulau datar dengan pasir putih yang ditumbuhi beberapa jenis pohon seperti pohon kelapa, semak dan rumput. Zona pemanfaatan terdapat disekeliling pulau dan dimanfaatkan untuk wisata pantai dan wisata bahari (Gambar 1). Arlius et al. (2017) menjelaskan bahwa Pulau Angso mempunyai potensi wisata pantai daya dukung wisata pantai 680 orang/ hari.

Pulau Tangah merupakan salah satu pulau dalam administrasi Kecamatan Pariaman Tengah, dengan koordinat terletak pada 00³8'51" LS dan $100^{\circ} 06^{\prime} 05^{\prime}$ ' BT. Luas Pulau Tangah adalah 6,3 Ha. Pulau ini tidak berpenduduk. Kata Tangah berarti letaknya di tengah. Kondisi umum Pulau Tangah merupakan pulau datar dengan pasir putih yang ditumbuhi beberapa jenis pohon seperti pohon kelapa, semak dan rumput. Zona pemanfaatan terdapat disekeliling pulau dan dimanfaatkan untuk wisata pantai dan wisata bahari (Gambar 1). Fajrin et al (2019) menjelaskan daya dukung wisata pantai di Pulau Tangah adalah 244 orang/ hari dengan luas total area 6,1 Ha.

Pulau Ujuang merupakan salah satu pulau dalam administrasi Kecamatan Pariaman Tengah, dengan koordinat terletak pada 00'39'37" LS dan $100^{\circ} 06$ '39” BT. Luas Pulau Ujuang adalah 3,25 Ha. Pulau ini tidak berpenduduk. Sedangkan kata Ujuang itu sendiri memiliki arti paling ujung. Kondisi umum Pulau Ujuang merupakan 
pulau datar dengan pasir putih yang ditumbuhi beberapa jenis pohon seperti pohon kelapa, semak dan rumput. Zona pemanfaatan terdapat disekeliling pulau dan dimanfaatkan untuk wisata pantai dan wisata bahari (Gambar 1). Utami et al (2018) menjelaskan bahwa Pulau Ujuang mempunyai kecerahan $25 \mathrm{~m}$, kecepatan arus 16,85 m/det, dan gelombang laut antara $60-80 \mathrm{~cm}$.

Pulau Kasiak merupakan salah satu pulau dalam administrasi Kecamatan Pariaman Utara, dengan koordinat terletak pada $00^{\circ} 35^{\prime} 47^{\prime \prime}$ LS dan 100 04'29” BT. Luas Pulau Kasiak adalah 2,0 Ha. Pulau ini tidak berpenduduk. Sedangkan kata Kasiek itu sendiri memiliki arti pasir. Kondisi umum Pulau Kasiak merupakan pulau datar dengan pasir putih yang ditumbuhi beberapa jenis pohon seperti pohon kelapa, waru laut, tanaman berbunga, semak dan rumput. Pulau ini memiliki mercusuar dan bangunan milik Kementrian Perhubungan. Zona inti terletak di utara dan selatan Pulau ini. Zona perikanan berkelanjutan terletak disisi barat dan timur pulau ini (Gambar 1). Zona inti digunakan untuk perlindungan penyu. Penyu yang dilindungi di KKPD Kota Pariaman adalah penyu sisik (Eretmochelys imbricata), penyu hijau (Chelonia mydas) dan penyu lekang (Lepidochelys olivacea). Kementerian Lingkungan Hidup dan Kehutanan (2018) melindungi jenis tumbuhan dan satwatermasuk 5 penyu yaitu penyu bromo (Caretta caretta), penyu hijau (Chelonia mydas), penyu sisik (Eretmochelys imbricata), penyu lekang (Lepidochelys olivacea), dan penyu pipih (Natator depressus). Menurut Sari et al. (2018) sarang penyu hijau (Chelonia mydas) di Pulau Kasiak memiliki tekstur pasir $>90 \%$ pasir, debu $3,4-7,25 \%$ dan liat 2-8 \%, suhu sarang $25-32^{\circ} \mathrm{C}$, kelembaban sarang $30-40 \%$, dan vegetasi yang dominan waru laut. Kondisi lingkungan perairan Pulau Kasiek dengan suhu $29-30^{\circ} \mathrm{C}$, salinitas 33-34 ppt, kecepatan arus 0,4-0,5 m/det dan $\mathrm{pH} 8$.

\section{Kegiatan yang boleh dan tidak boleh dilakukan di Zona Inti}

Zona inti berdasarkan Peraturan Menteri Kelautan dan Perikanan No.30/2010 yaitu kawasan yang harus dilindungi, tidak diperbolehkan merubah kondisi yang ada, kecuali yang berhubungan dengan ilmu pengetahuan, pendidikan, perlindungan, serta pemulihan dan pelestarian lingkungan. Kegiatan-kegiatan yang disarankan untuk zona ini dalam bentuk konservasi dan pemulihkan kawasan agar biota yang berada di zona ini dapat berkembang biak sebagaimana semestinya. Menurut Kementrian Kelautan dan Perikanan (2010), zona inti yang wajib dimiliki oleh kawasan konservasi perairan minimal 2\% (dua persen) dari luas total kawasan. Hal senada dinyatakan oleh Yonvitner et al. (2019) melaporkan bahwa luas zona inti di Kawasan Konservasi Perairan Kapoposang adalah $2,16 \%$.

Kondisi karang di zona inti di sebelah selatan Pulau Kasiek dengan koordinat $100^{\circ} 04^{\prime} 33.8^{\prime \prime}$ BT dan $00^{\circ}$ 35'52.0" LS mempunyai tutupan karang hidup sebesar 28,53 (kategori sedang). Sedangkan kondisi karang zona inti di sebelah utara Pulau Kasiek dengan $\begin{array}{lllll}\text { koordinat } 100^{\circ} & 04^{\prime} & 27.2^{\prime \prime} & \mathrm{BT} \text { dan } 00^{\circ}\end{array}$ 35'41.7" LS mempunyai tutupan karang hidup sebesar 26,33\% (kategori buruk) (Dinas Kelautan dan Perikanan Provinsi Sumatera Barat, 2018). Kerusakan terumbu karang di zona inti karena peristiwa pemutihan karang (coral bleaching) di seluruh perairan Sumatera Barat pada pertengahan tahun 2016 (Suparno et al., 2018). Adapun bentukbentuk kegiatan yang boleh ataupun yang tidak boleh tercantum pada Tabel 2 . 
Tabel 2. Kegiatan yang boleh dan tidak boleh dilakukan di zona inti

\begin{tabular}{|c|c|c|c|c|c|}
\hline \multirow{3}{*}{$\begin{array}{l}\text { No. } \\
\text { A. }\end{array}$} & \multirow[b]{2}{*}{ Indikator } & \multirow[b]{2}{*}{ Arahan } & \multicolumn{3}{|c|}{ Rekomendasi } \\
\hline & & & Boleh & $\begin{array}{c}\text { Boleh } \\
\text { Bersyarat }\end{array}$ & $\begin{array}{l}\text { Tidak } \\
\text { Boleh } \\
\end{array}$ \\
\hline & Berdasarkan Potensi & & & & \\
\hline 1 & $\begin{array}{l}\text { Wisata Bahari } \\
\text { - Snorkeling } \\
\text { - Diving } \\
\text { - Berenang } \\
\text { - Memancing } \\
\text { - Pembuatan foto, video, } \\
\text { film } \\
\text { - Perahu wisata }\end{array}$ & $\begin{array}{l}\text { - Perlindungan } \\
\text { habitat dan } \\
\text { populasi ikan; } \\
\text { - Penelitian; } \\
\text { - Pendidikan. }\end{array}$ & & & $\sqrt{ }$ \\
\hline 2 & $\begin{array}{l}\text { Penelitian } \\
\text { - Peneluran Penyu, Lola, } \\
\text { Kima } \\
\text { - Terumbu Karang }\end{array}$ & & $\sqrt{ }$ & & \\
\hline 3 & Penangkapan ikan/biota & & & & $\sqrt{ }$ \\
\hline B. & Berdasarkan Aktivitas & & & & \\
\hline 1. & $\begin{array}{l}\text { Pemulihan dan rehabilitasi } \\
\text { lingkungan/ekosistem }\end{array}$ & & $\sqrt{ }$ & & \\
\hline 2. & Lego jangkar & & & & $\sqrt{ }$ \\
\hline 3. & $\begin{array}{l}\text { Pemasangan rumpon } \\
\text { perikanan }\end{array}$ & & & & $\sqrt{ }$ \\
\hline 4. & Aktivitas budidaya & & & & $\sqrt{ }$ \\
\hline 5 & $\begin{array}{l}\text { Menghilangkan fungsi } \\
\text { kawasan dan luasan zona } \\
\text { pemanfaatan }\end{array}$ & & & & $\sqrt{ }$ \\
\hline 6. & Restocking alami & & $\sqrt{ }$ & & \\
\hline
\end{tabular}

\section{Kegiatan yang boleh dan tidak boleh dilakukan di Zona Perikanan Berkelanjutan}

Peraturan Menteri Kelautan dan Perikanan No.30/2010 menjelaskan bahwa zona perikanan berkelanjutan mempunyai kegiatan perlindungan dan pelestarian habitat dan populasi ikan dalam bentuk menjaga, mengelola dan memulihkan atau rehabilitasi biota dan ekosistemnya. Kegiatan-kegiatan yang di arahkan untuk zona perikanan berkelanjutan bertujuan agar menunjang kelestarian sumberdaya perairan dan habitatnya.

Aktifitas penangkapan ikan di zona perikanan berkelanjutan dilakukan oleh kapal penangkap ikan paling besar 10 GT dan penangkapan ikan tidah boleh melebihi daya dukung kawasan paling banyak $50 \%$. Metode penangkapan ikan tidak boleh membahayakan manusia, merusak sumberdaya ikan dan menimbulkan konflik antar nelayan. Dalam zona perikanan berkelanjutan dilarang mengunakan alat bantu penangkapan berupa rumpon ikan. Alat yang direkomendasikan adalah jaring angkat, jaring insang, perangkap, pancing, alat penjepit dan melukai.

$\begin{array}{rrrr} & \text { Survey } & \text { ekosistem } & \text { terumbu } \\ \text { karang } & \text { di } & \text { KKP } & \text { Kota }\end{array}$ Pariamanmenemukan jenis ikan famili Chatodontidae seperti Chaetodon triangulum, C. Collare, C. rafflesii, C, vagabundus, C. trifasciatus, Forcipiger flavissimus, Heniochus singularis, $H$. acuminatus dan $H$. pleurotaenia. Jenis yang dominan famili Chatontidae adalah 
Heniochus pleurotaenia. Ikan herbivora diwakili oleh famili Acanthuridae dan famili Scaridae. Ikan karnivora diwakili oleh famili Lutjanidae, famili Serranidae dan famili Haemulidae (Dinas Kelautan dan Perikanan Provinsi Sumatera Barat, 2018). Adapun kegiatan yang diperbolehkan dan dilarang di zona perikanan berkelanjutan dapat dilihat pada Tabel 3.

\section{Kegiatan yang boleh dan tidak boleh dilakukan di Zona Pemanfaatan}

Sesuai dengan Peraturan Menteri

Kelautan dan Perikanan No.30/2010 untuk zona pemanfaatan sudah menekankan kepada unsur komersial. Dimana zona ini boleh dimanfaatkan untuk pariwisata, penelitian dan pengembangan serta pendidikan untuk masyarakat umum. Pemanfaatannya tidak boleh secara intensif sehingga merusak ekosistem perairan.

Kegiatan di zona pemanfaatan dapat digunakan untuk kegiatan pariwisata alam perairan seperti wisata selam, wisata pancing, wisata perahu layar, wisata snorkling, wisata tontonan, pembuatan foto, video, film komersial, wisata berenang dan wisata/ olahraga air lainnya. Pengusahaan alam perairan meliputi penyediaan infrastruktur, penyediaan alat, penyediaan jasa transportasi dan jasa pramuwisata.

Zona pemanfaatan di KKPD Kota Pariaman ini digunakan untuk wisata pantai dan wisata bahari. Utami et al (2018) menjelaskan bahwa pulau-pulau kecil di Kota Pariaman sangat cocok untuk wisata memancing, berenang, menyelam dan berperahu karena kecerahan, arus, gelombang dan aksesibilitasnya sangat mendukung kegiatan tersebut. Ondara et al. (2018) menyebutkan bahwa kondisi pasang surut di pesisir Kota pariaman adalah tipe campuran harian ganda (mixed semidurnal Tide) dan kecepatan arusnya berkisar 0-0,03 $\mathrm{m} / \mathrm{det}$ dengan dominan arahnya tegak lurus pantai. Kegiatan yang bisa dilaksanakan di zona pemanfaatan dapat dilihat pada Tabel 4.

Tabel 3. Kegiatan yang boleh dan tidak boleh dilakukan di zona perikanan berkelanjutan

\begin{tabular}{|c|c|c|c|c|c|}
\hline \multirow[b]{2}{*}{ No. } & \multirow[b]{2}{*}{ Indikator } & \multirow[b]{2}{*}{ Arahan } & \multicolumn{3}{|c|}{ Rekomendasi } \\
\hline & & & Boleh & $\begin{array}{c}\text { Boleh } \\
\text { Bersyarat }\end{array}$ & $\begin{array}{l}\text { Tidak } \\
\text { Boleh }\end{array}$ \\
\hline A. & Berdasarkan Potensi & & & & \\
\hline 1 & $\begin{array}{l}\text { Wisata Bahari } \\
\text { - Snorkeling } \\
\text { - Diving } \\
\text { - Berenang } \\
\text { - Memancing } \\
\text { - Pembuatan foto, video, } \\
\quad \text { film } \\
\text { - Perahu wisata }\end{array}$ & $\begin{array}{l}\text { - Perlindungan } \\
\text { habitat dan } \\
\text { populasi ikan; } \\
\text { - Penangkapan ikan } \\
\text { dengan alat dan } \\
\text { cara yang ramah } \\
\text { lingkungan; } \\
\text { - Pariwisata dan } \\
\text { rekreasi. }\end{array}$ & $\sqrt{ }$ & & \\
\hline 2 & $\begin{array}{l}\text { Wisata Darat } \\
\text { - Camping } \\
\text { - Menjelajah pulau } \\
\text { - Pembuatan foto, video, } \\
\text { film } \\
\text { - Outbound training } \\
\text { - Site pengamatan penyu }\end{array}$ & & $\sqrt{ }$ & & \\
\hline 3 & $\begin{array}{l}\text { Penelitian: Peneluran } \\
\text { Penyu, Lola, Kima, } \\
\text { Terumbu Karang }\end{array}$ & & $\sqrt{ }$ & & \\
\hline 4 & Penangkapan ikan/biota & & $\sqrt{ }$ & & \\
\hline
\end{tabular}


Lanjutan Tabel 3.

\begin{tabular}{|c|c|c|c|c|c|}
\hline No & Indikator & Arahan & Boleh & Boleh Bersyarat & Tidak Boleh \\
\hline B. & Berdasarkan Aktivitas & & & & \\
\hline 1 & $\begin{array}{l}\text { Pemulihan dan rehabilitasi } \\
\text { lingkungan/ekosistem }\end{array}$ & & $\sqrt{ }$ & & \\
\hline 2 & Lego jangkar & & & $\sqrt{ }$ & \\
\hline 3 & Pemasangan rumpon & & $\sqrt{ }$ & & \\
\hline 4 & Aktivitas budidaya & & $\sqrt{ }$ & & \\
\hline 5 & $\begin{array}{l}\text { Menghilangkan fungsi } \\
\text { kawasan dan luasan zona } \\
\text { pemanfaatan }\end{array}$ & & & & $\sqrt{ }$ \\
\hline 6 & Restocking alami & & $\sqrt{ }$ & & \\
\hline
\end{tabular}

Tabel 4.Kegiatan yang boleh dan tidak boleh dilakukan di zona pemanfaatan

\begin{tabular}{|c|c|c|c|c|c|}
\hline \multirow[b]{2}{*}{ No } & \multirow[b]{2}{*}{ Indikator } & \multirow[b]{2}{*}{ Arahan } & \multicolumn{3}{|c|}{ Rekomendasi } \\
\hline & & & Boleh & $\begin{array}{c}\text { Boleh } \\
\text { Bersyarat }\end{array}$ & $\begin{array}{l}\text { Tidak } \\
\text { Boleh }\end{array}$ \\
\hline A. & Berdasarkan Potensi & & & & \\
\hline 1 & $\begin{array}{l}\text { Wisata Bahari } \\
\text { - Snorkeling } \\
\text { - Diving } \\
\text { - Berenang } \\
\text { - Memancing } \\
\text { - Pembuatan foto, video, } \\
\text { film } \\
\text { - Perahu wisata }\end{array}$ & $\begin{array}{l}\text { - Perlindungan dan } \\
\text { pelestarian habitat } \\
\text { dan populasi ikan; } \\
\text { - Pariwisata dan } \\
\text { rekreasi; } \\
\text { - Penelitian dan } \\
\text { pengembangan; } \\
\text { - Pendidikan. } \\
\end{array}$ & $\sqrt{ }$ & & \\
\hline 2 & $\begin{array}{l}\text { Wisata Darat } \\
\text { - Camping } \\
\text { - Menjelajah pulau } \\
\text { - Pembuatan foto, video, } \\
\text { film } \\
\text { - Outbound training } \\
\text { - Site pengamatan penyu } \\
\end{array}$ & & $\sqrt{ }$ & & \\
\hline 3 & $\begin{array}{l}\text { Penelitian } \\
\text { - Peneluran Penyu, Lola, } \\
\text { Kima } \\
\text { - Terumbu Karang }\end{array}$ & & $\sqrt{ }$ & & \\
\hline 4 & Penangkapan ikan/biota & & & & $\sqrt{ }$ \\
\hline B. & Berdasarkan Aktivitas & & & & \\
\hline 1 & $\begin{array}{l}\text { Pemulihan dan rehabilitasi } \\
\text { lingkungan/ekosistem }\end{array}$ & & $\sqrt{ }$ & & \\
\hline 2 & Lego jangkar & & & $\sqrt{ }$ & \\
\hline 3 & $\begin{array}{l}\text { Pemasangan rumpon } \\
\text { perikanan }\end{array}$ & & & & $\sqrt{ }$ \\
\hline 4 & Aktivitas budidaya & & & & $\sqrt{ }$ \\
\hline 5 & $\begin{array}{l}\text { Menghilangkan fungsi } \\
\text { kawasan dan luasan zona } \\
\text { pemanfaatan }\end{array}$ & & & & $\sqrt{ }$ \\
\hline 6 & Restocking alami & & $\sqrt{ }$ & & \\
\hline
\end{tabular}




\section{KESIMPULAN}

Hasil analisis Rencana Zonasi Kawasan Konservasi Kota terbagi atas 3 zona yaitu zona inti, zona perikanan berkelanjutan dan zona pemanfaatan. Zona inti digunakan untuk perlindungan habitat ikan dan populasi ikan, pendidikan dan penelitian. Zona perikanan berkelanjutan digunakan untuk perikanan tangkap, wisata pantai dan wisata bahari. Zona pemanfaatan digunakan untuk wisata pantai dan wisata bahari.

Kegiatan yang dibolehkan di zona inti, zona perikanan berkelanjutan dan zona pemanfaatan adalah kegiatan mendukung kelestarian dan memperhatikan daya dukung kawasan konservasi. Kegiatan yang tidak dibolehkan di zona inti, zona perikanan berkelanjutan dan zona pemanfaatan adalah kegiatan merusak ekosistem perairan dan kegiatan tidak memperhatikan daya dukung kawasan konservasi perairan

\section{DAFTAR PUSTAKA}

Arlius, Bulanin, U., Mayasari, L., 2017., Kajian Kesesuaian Lahan Wisata Pantai di Pulau Angso Duo Kota Pariaman, Sumatera Barat. Prosiding Seminar Nasional Kelautan dan Perikanan III, Universitas Trunojoyo, 7 September 2017: 1-12.

Cheng, B.S., Altieri, A.H., Torchin, M.E., Ruiz, G.M., 2019. Can Marine Reserves Restore Lost Ecosystem Functioning? A Global Synthesis. Ecology 100 (4):1-13. https://doi.org/10.1002/ecy.2617

Dinas Kelautan dan Perikanan Provinsi Sumatera Barat., 2018. Penyediaan Data Series Keanekaragaman Hayati dan Sumberdaya Ikan Kawasan Konservasi Perairan Daerah (KKPD) Provinsi Sumatera Barat, Kota Padang dan Kota Pariaman. Padang. 64 hal.

Dinas Kelautan dan Perikanan Provinsi Sumatera Barat., 2019. Data
Statistik Kelautan, Pesisir dan Pulau-Pulau Kecil. Padang. 68 hal.

Fajrin, B., Suparno dan Arlius., 2019. Analisis Kesesuaian Lahan dan Daya Dukung Lahan Wisata Pantai di Pulau Tangah Kota Pariaman, Sumatera Barat. Prosiding Hasil Penelitian Mahasiswa FPIK. Fakultas Perikanan dan Ilmu Kelautan, Universitas Bung Hatta: 15-25.

Giakoumi, S., Scianna, C., PlassJohnson, J., Micheli, F., GrorudColvert, K., Thiriet, P., Claudet, J., Carlo, G.D., Franco, A.D., Gaines, S.D., Garcia- Charton, J.A, Lubchenco, J., Reimer, J., Sala, E., Guidetti, P., 2017. Ecological Effects of Full and Partial Protection in the Crowded Mediterranean Sea: a Regional Meta-Analysis. Science Report 7 (8940): $1-12$. https://doi.org/10.1038/s41598017-08850-w

Harmelin-Viviena, M., Le Direach, L., Bayle-Sempere, J., Chabonnel, E., Garcia-Charton, J.A., Ody. D., Perez-Ruzafa, A., Renones, O., Sanchez-Jerez, P., Valle, C., 2008. Gradients of abundance and Biomassa Across Reserve Boundaries in Six Mediterranean Marine Protected Areas: Evidence of Fish Spillover? Biological Conservation 141 (7): 1829-1839. https://doi.org/10.1016/j.biocon.2 008.04.029

Kementrian Kelautan dan Perikanan., 2010. Peraturan Menteri Kelautan dan Perikanan Republik Indonesia No30/MEN/2010 tentang Rencana Pengelolaan dan Zonasi Kawasan Konservasi Perairan. Jakarta. 14 hal.

Kementrian Kelautan dan Perikanan., 2014. Panduan Penyusunan Rencana Pengelolaan dan Zonasi Kawasan Konservasi Perairan, Pesisir dan Pulau-Pulau Kecil. Direktorat Jenderal Kelautan, Pesisir dan Pulau-Pulau Kecil, 
Kementrian Kelautan dan Perikanan. Jakarta. 207 hal.

Kementrian Lingkungan Hidup dan Kehutanan Republik Indonesia., 2018. Peraturan Menteri Kehutanan dan Lingkungan Hidup No P.100/MENLHK/SETJEN/KUM. $1 / 12 / 2018$ tentang jenis tumbuhan dan satwa yang dilindungi. Jakarta. 31 hal.

Krueck, N.C., Ahmadja, G.N., Possingham, H.P., Rginos, C., Treml, E.A, Mumby, P.J., 2017., Marine Reserve Targets to Sustain and Rebuild Unregulated Fisheries. PloS Biology 15 (1): 120.https://doi.org/10.1371/journal. pbio. 2000537

Ondara, K., Rahmawan, G.A. Pitri, Y.A., 2018. Kerentanan Pesisir Kota Pariaman, Sumatera Barat Menggunakan Pemodelan Numerik Hidro-Osenaografi. Prosiding Seminar Nasional Kelautan dan Perikanan IV. Universitas Trunojoyo. 5 September 2018: 13-24.

Perez-Ruzafa, A., Garcia-Charton, JA., Marcos, C., 2017. North East Atlantic vs. Mediterranean Marine Protected Areas as Fisheries Management Tool. Frontiers in Marine Science 4 (245): 1-13. https://doi.org/10.3389/fmars.201 7.00245

Rodwell, L.D., Barbier, E.B., Roberts, C.M., McClanahan, T.R., 2003. The Importance of Habitat Quality for Marine Reserve Fishery Linkages. Canadian Journal of Fisheries and Aquatic Science 60 (2): 171-181. https://doi.org/10.1139/F03-009

Sala, E., Giakoumi, S., 2017. No-Take Marine Reserves are the Most Effective Protected Area in The Ocean. ICES Journal of Marine Science $\quad 2$ : 1-3 https://doi.org/10.1093/icesjms/fs x059
Sari, D.N., Fauzi, M., Sumiarsih, E., 2018. Karakteristik Sarang Penyu Hijau (Chelonia mydas) di Pulau Kasiek Kawasan Konservasi Penangkaran Penyu Pariaman, Sumatera Barat. Berkala Perikanan Terubuk 46 (2): 42-49.

Suparno, Munzir, A., Suryani, K.,2018., Transplantasi Karang Hias untuk Mendukung Wisata Selam di Nagari Sungai Pinang, Kabupaten Pesisir Selatan. Jurnal Vokasi 2 (1): 60-65.

Utami, E., Triyatmo dan Antomi, Y., 2018., Potensi Pulau-Pulau Kecil untuk Wisata Pantai di Kota Pariaman. Junal Buana 2 (1): 154166.

Yonvitner, Faisol, L., Yasir, Ilham., 2019. Multi-Criteria Analysis (MCA) for Fisheries Management in Marine Conservation Area, Kapoposang Islands. Jurnal Perikanan dan Kelautan Tropis 10 (3): 92101.https://doi.org/10.35800/ipkt. $\underline{10.3 .2019 .26089}$ 